\title{
Comparative Study on Travel Agency Management System in Mainland China, Hong Kong and Taiwan
}

\author{
Ji Wen, Pingping Hou \\ Department of Tourism Management, School of Management, Jinan University, Guangzhou, China \\ Email: twenji@jnu.edu.cn, grasshou@163.com
}

Received 9 January 2015; accepted 25 January 2015; published 29 January 2015

Copyright (C) 2015 by authors and Scientific Research Publishing Inc.

This work is licensed under the Creative Commons Attribution International License (CC BY). http://creativecommons.org/licenses/by/4.0/

c) (7) Open Access

\begin{abstract}
Tourism is one of the pillar industries in Hong Kong and Taiwan; they have accumulated a set of more perfect and mature management system in travel agency and operation mechanism. The current development of China's travel industry still has a lot of room for improvement. Referencing and learning travel agency industry management experience of Hong Kong and Taiwan will promote our tourism industry management process. The study focuses on the difference of the mainland, Hong Kong, Taiwan's tourism management system and their respective advantages of management. Then it puts forward corresponding suggestions according to the present situation of the development of travel industry of the mainland, and provides reference for the travel industry management and the organization system innovation.
\end{abstract}

\section{Keywords}

Mainland China, Hong Kong, Taiwan, Travel Agency, Management System

\section{Introduction}

The promulgation and implementation of "Tourism Law" will have an important impact on the development of China's travel agency; promulgating the “Tourism Law” indicates that China's tourism industry will officially enter the historical stage of the legal basis. China tourism industry's first law will create a favorable legal environment for the healthy and sustainable development of tourism industry, to promote the upgrading of industrial structure of travel agency and the transformation of the growth mode. However, the promulgation of "Tourism Law" only provides a legal guarantee for the development of the travel agency industry. At the present stage of China's travel agency industry, there are still many problems needed to be solved and perfected. The industry is 
one of the pillar industries in Hong Kong and Taiwan; they have accumulated a set of more perfect and mature management system for travel agency and operation mechanism. Referencing and learning from Hong Kong, Taiwan travel agency management experience will play an important role in promoting the process of China's travel agency management. The study focuses on the difference of the mainland, Hong Kong, Taiwan's tourism management system and their respective advantages of management. Then it puts forward corresponding suggestions according to the present situation of the development of travel industry of the mainland, and provides reference for the travel industry management and the organization system innovation.

\section{Comparison of the Tourism Industry Management Mechanism}

\subsection{Mainland China Tourism Industry Management Institutions}

Mainland China's tourism industry management department is the official organization People’s Republic of China National Tourism Administration. China National Tourism Administration is a national administrative body under the State Council which is mainly responsible for the national tourism industry. Its main duty is to coordinate the development of tourism, make the tourism industry's policies, plans and standards, draft up relevant laws and regulations and supervise their implementation. It has to monitor tourism economic operation, responsible for tourism statistics and dissemination industry information. It also commitment to regulate the tourism market order and management service quality, which responsible for protect tourism consumers and operators' legal rights. The National Tourism Administration guide the tourism industry spiritual civilization construction operations, credit system construction and industry organizations, certificate issuing and management of hotel, travel agencies, tour guides in the travel industry. It promoting international exchange and cooperation in tourism, take charge of affairs relating to the cooperation with the international tourism organization. The department has developing tourism personnel planning and guiding tourism training. It has to organize outreach and dissemination of tourism information and coordinate economic relations between enterprises departments. It is responsible for tourism security management, supervision and timely resolve tourism problems [1].

Tourism Bureau of the provinces, municipalities and autonomous regions is directly under the central government. Tourism Bureau is the administration management of local tourism destination, which by the local Party committee, government and National Tourism Administration of the dual leadership. It is responsible for the administrative management of tourism planning, management and coordination. Its main responsibility is to implement the National Tourism Administration to make the tourism plans, policies and guidelines. It has to manage the region's tourism businesses and promote the tourism development in its region.

\subsection{Hong Kong Tourism Industry Management Authorities}

There are three main departments in Hong Kong that relates to tourism management. It is the government of the HKSAR Tourism Commission. Tourism Board is the semi-official organizations in Hong Kong. Travel Industry Council is the industry organizations of Hong Kong.

\subsubsection{Hong Kong Tourism Commission}

Tourism Commission is the government tourism management department which under the Commerce and Economic Development Bureau [2]. It is headed by the tourism affairs Commissioner. Tourism Commission's main responsibility is to develop and coordinate the implementation of the policies, strategies and plans of tourism developing. It has to contact with other industries and promote the development of tourism. Tourism Commission is also responsible for the coordination with other government bureaus and departments. It has to implement policies and measures the impact on the tourism industry. The Tourism Commission is internally provided with Travel Agents Registry. It is the executive body of Hong Kong "Travel Agents Ordinance”. Tourism Commission is responsible for issuing a new travel agent's license administration and management travel agents. It needs to provide support services to the secretariat of the Advisory Committee on Travel Agents and management the travel industry compensation fund and other functions.

\subsubsection{Hong Kong Tourism Board}

Hong Kong Tourism Board is a government-funded agency. Hong Kong Tourism Board’s governing body has 20 members who were appointed by the Hong Kong SAR Government [3]. Its main functions are expanding the 
tourism contribution to Hong Kong. It has to promote Hong Kong brands to the tourism customers and the media around the world as well as enrich visitors' experience during Hong Kong. It has to create business platform for Hong Kong tourism industry. It needs to promote the improvement of tourist facilities and support services for visitors to enjoy Hong Kong people's daily activities. It also has to promote the above matters can be taken. It is to make recommendations and advices to the Chief Executive of the HKSAR. It can improve tourist facilities. It has to provide services to visitors who traveling in Hong Kong. In order to achieve these goals, the Hong Kong Tourism Board maintains close cooperation with the relevant government departments, agencies, tourism industry and other direct or indirect tourism-related institutions. In addition, Hong Kong Tourism Board make extensive passenger research surveys and gather information from various aspects of tourist's traits, preferences, etc. Then it needs to formulate appropriate tourism promotion policies and strategies for different population groups and tourism source markets.

\subsubsection{Travel Industry Council of Hong Kong}

Travel Industry Council is establishment under the "Travel Agents Ordinance”, which is the tourism industry organization of Hong Kong. It is responsible for the supervision and management of overseas tour and inbound travel [4]. Its goal is to maintain a high professional level of tourism service and protect the interests of tourists and tourism dual practitioners. Travel Industry Council including eight affiliated members and more than 1500 travel agencies. Travel Industry Council including the Council, the Appeal Board, 16 professional committees and parliamentary offices. It mainly provided service for members and the public. It organizing various activities to promote friendly relations and understanding of the industry. It also provided training courses, seminars and workshops to enhance the quality of practitioners. The publication of periodical publication and updating parliament website that provides all kinds of information to members, mediate disputes, industry members and the public. It can facilitate communication outside the industry-related organizations and provide consultation channels [5]. It can raise consumer awareness of tourism to protect the safety, handling inquiries and complaints from travelers.

\subsection{Taiwan's Tourism Industry Management Authorities}

Taiwan's tourism industry management department is the government affiliated institutions which is the Taiwan Tourism Bureau Ministry of Transportation. The bureau currently consists of 5 working groups: marketing, business, technology and international tourism island residents; It also has 4 offices: secretary, personnel, accounting and ethics [6]. It has a director and two deputy director. The Tourism Bureau is responsible for the leadership and management. The main responsibilities are: tourism survey planning, construction and promotion. As well as the issuance of documents and management of hotels, travel agencies and tour guides in the travel industry. It also has to responsible for tourism practitioners training and assessment. It needs to responsible for tourism resources protection and management and make standard and assessment of accommodation and catering. It has to investigation and research on tourism market and promotion Taiwan's tourism resources and tourism brand to the publicity around the world. It should promote exchanges and cooperation between all levels of tourism organizations.

\section{Comparative Study of Travel Agency Management System}

\subsection{Travel Agency Management System in Mainland China}

The administrative department of government is mainly in charge of travel agency industry in mainland China. In other words, the National Tourism Administration is responsible for the national travel agency management. It is the quality specification of National Tourism Administration and management department to directly lead the travel industry's daily management function. "Travel regulations" provisions of article third: the administrative department of the State Council should responsible for the national tourism travel agency supervision and management. The local tourism departments have to management travel agency in accordance with the duties of supervision and administration in their respective administrative areas. The local governments of commerce, price, business, foreign exchange and other relevant departments should follow the division of responsibilities and work with the local travel agencies. The local Tourism Bureau under the leadership of the local people's government in the administrative and accept guidance superiors in business from higher level Tourism Bureau. 
In mainland China the travel agency industry management is issued by the ministry of the national travel agency industry management laws, policies and guidelines, and local governments, legislatures. The industry is issued by the department of policies, decrees and regulations elements such as file rules.

\subsection{Travel Agency Management System of Hong Kong}

Hong Kong's travel agency is co-management by the official of the Hong Kong Tourism Commission and industry associations of Travel Industry Council of Hong Kong. Hong Kong Tourism Commission has the Travel Agents Registry which is the executive body of Hong Kong "Travel Agents Ordinance”. It is responsible for issuing new travel agents licenses management and travel agents management. The Advisory Committee on travel agents to provide secretariat support services, the travel industry compensation fund management and other functions. Hong Kong Travel Industry Council is an industry association of travel agency in Hong Kong. The "travel agents regulations" is regulations for all travel agents. It must be management by parliament. One of the conditions is travel agents must be license issued and become a member of parliaments. It has to receive the new travel agents license and makes the Travel Industry Council of the industry to achieve 100\% coverage. The Travel Industry Council on behalf of the "tourism compensation fund management committee" to collecting stamp fees and maintenance of printing machine. Travel Industry Council and Tourism Commission are co-managed travel agents. They are complements each other and cross-representation. But the Travel Industry Council of Hong Kong is the main department of the daily management to management the travel agency industry.

\subsection{Taiwan Travel Agency Management System}

The provisions of the Taiwan travel agency management rule: the Taiwan Tourism Bureau is responsible for the specific implementation of the travel agencies establishment, modification or dissolution of registration, business license, management, rewards, punishment, management managers and practitioners. In addition to the official Tourism Bureau, Taiwan travel industry Quality Assurance Association is the industry association which is an important management of travel agencies. Taiwan Travel Quality Assurance Association is mainly responsible for the supervision and management of travel agencies. The main purpose is to improve the tourism quality, safeguard the rights and interests of tourists. Travel Quality Assurance Association was founded in 1989. It is the self-discipline of a social welfare organization was composed by travel agents to protect their own travel consumer. It makes the tourism consumers have adequate protection and help its members. It has to make travel agency has the reasonable business space. The association has a member travel corporation head office which have 2436,749 branch companies that accounting for about nine of the total number of all travel agencies in Taiwan. The Quality Assurance Association was funded by the member. The fund is divided into two parts. There are the Permanent Fund and the United Nations Fund and with interest on the fund as conference promotion.

\section{Respective Advantages of Travel Agency Management in Mainland China, Taiwan and Hong Kong}

\subsection{The Advantages of Travel Agency Management in Mainland China}

In mainland China, the Travel Agencies development is dominated by the government. It has unique advantages. Such as: direct and effective, information-rich, cash-rich and strong coordination advantages [7]. The government is accordance with the reality of the problems to make tourism industry development laws and policies to guide the sustainable and healthy development of the tourism industry. The government can effective coordination social forces and provides internal and external good environment for tourism development. The government can carry out large-scale investment to improve the tourism infrastructure and stimulate tourism consumption demand. Through the power of government can effectively protect tourism resources and timely stop certain violations and make effective punishment. The government can make policies to ensure tourism market orderly operation, promote enterprise legal management, makes the fair and free competition in the tourism market [8]. The government can take visitors as center for the establishment of nationwide tourism public service platform and satisfy the citizen tourism and leisure needs. It can provide high quality and inexpensive public tourism products and improve the supply of tourism products quality. Government departments can unify the tourism 
destination image; have enough material and financial resources for tourism promotion to the world, to enhance the national tourism image and reputation [9]. It can promote tourism cooperation and exchange between countries and regions. The government can make policies and regulations to carry out and implement effectively. It can effectively coordinate the contradictions and conflicts of interest in different areas of tourism, formulate unified tourism development planning, promote harmonious development of travel industry [10].

\subsection{The Advantage of Travel Agency Management in Hong Kong}

The official sector and industry organizations are co-management travel agents in Hong Kong. Tourism management authority in each function set and allocation of both advocates mutual cooperation and also stressed operate independently of each other. There are fully reflected the market economy mode that operation of small government, big market, socialization and professional operation. The Hong Kong Tourism agency management structure is based on the development needs of the travel industry and the corresponding functions division. It was eventually formed after several reforms established. The main advantage is make the law gives the Travel Industry Council oversight authority and responsibility to manage and promote the tourism development. It can ensure the authority and effectiveness management of travel agencies and tour guides and promotional. The Travel Industry Council can operation funds pragmatic and in a flexible way to provide a strong economic support for the relevant departments to perform their duties. Members in Hong Kong's tourism management mechanism are with broad representation. They come from different industries and sectors that help to arouse the enthusiasm of the relevant industries and organizations. It can conducive to the formation of professional and scientific decision-making. This organization also fully embodies the characteristics of high degree comprehensiveness and relevance of tourism industry. It can also conducive to promote the coordination management work. Tourism industry organizations in the rules of procedure conveniently and efficient can make a rapid response and positive measures to aim at the present problems in the tourism industry. It can maintain high efficiency of decision and strong executive ability.

\subsection{The Advantage of Travel Agency Management in Taiwan}

In Taiwan, the official department is the one which manage the travel agencies and gives full play to the function and role of industry association. Taiwan Tourism Bureau is the official management department. It can make the advantages of tourism management official. Such as: to develop reasonable plans of the island's tourism development, develop policies and regulations to protect the tourism market operation order, develop various tourism services specifications and standards to protect quality of tourism services. Tourism Bureau through diversified promotion improve Taiwan's tourism destination image. Tourism Bureau division some part rights to Taiwan Travel Security Association and let the association part can fully mobilize the enthusiasm of the work to provide opinions and suggestions for the government. It can play the intermediary role to association members' views to the government reaction to safeguard the interests of the members. Help develop association self-discipline function to protect tourism service quality and safeguard the rights and interests of tourists. The industry association to standard the enterprises behavior can be better for enterprises to promote the healthy development of tourism industry.

\section{Implications for the Development of China's Travel Industry}

Through comparison analysis of the three travel agency management system, there are some conclusions: Hong Kong and Taiwan have established independent industry associations. They don't belong to any government department association. They have certain rights to protect their sources of funding and play the role of associations in the travel industry management. The mainland China has also set up the tourism industry association organizations. But the group is essentially a government affiliated institutions that accept the leadership of the National Tourism administration. The Tourist Association mostly held by leading government officials and fewer people from the industry [11]. Tourist Association's activities are funded primarily from membership dues that lack of activity funds. Travel agency are join voluntarily and only a small part of the tourism enterprises to join in the association. The impact on the tourism industry of binding is small. The mainland China should strengthen the construction of travel industry associations and the role of Association. There are some suggestions towards mainland China travel agent development [12]. 


\subsection{Strengthening the Construction of Travel Agency Association and Give Full Play to the Role of the Association}

Government tourism departments should transfer some functions to the travel industry association. Government should be separated from the Tourist Association and maintain the independence of the Tourist Association. Government should grant Tourism Association corresponding supervisory powers and maintain their independence to work closely with each other. Such as: the supervision and management of travel agencies and tour guides can be handed over to the self-discipline management association and some micro transaction execution, technology can also let industry associations responsible for [13]. The government can transferred or entrusted some functions to the travel industry association. It can responsible for the tourism quality management, tour guide examination and training, travel industry standardization work, tourism industry survey, collect industry information and make industrial development planning [14].

\subsubsection{Improve the Self-Discipline Mechanism of Travel Industry Association}

Development and operation of Tourism Association has its own characteristics and laws. The planning and functions and the service procedures should accordance with the needs of the travel industry. The tourism industry association has its own characteristic. The association can management themselves by self-discipline, self-management and increasing the content of service association. To develop tourism association supervision and management system and mechanism based on democracy, equality, cooperation. Tourism association established daily office sector to provide timely and effective services to its members. Self-management of Travel Industry Association is more economical than the government which can effectively compensate for the lack of government management [15].

\subsubsection{Vigorously Develop the Travel Agency Members}

Government should ensure the independence of associations which can make it truly representative of the interests of the Association members. Learn travel agencies management system from the Travel Industry Council of Hong Kong and mandatory for travel agencies join the industry associations and improve the status of the travel industry associations. The members can play activities role in the organization. Actively seek tourism related enterprises of different industries to join the Tourism Association. The members of diversification can better coordinate all aspects to promote the tourism industry development [16]. In the fight for tourism enterprises to join the association that can be considered by pay membership dues level to different number of voting rights, strengthen the attraction of the industry association.

\subsection{Increase Funding of Travel Agency Industry Organization}

The government should provide funding assistance to association to protect the normal operation of tourism industry association. Lack of funds is the most important factor restricting the development of tourism industry associations and organization activities. On the one hand, government departments need to increase financial support; on the other hand, the needs of the tourism industry association to create a mechanism for sufficient funds to guarantee the normal operation of the association's activities and work. The tourism association can learn from Hong Kong to raise funds in a similar form of printing costs. The fund is a tourist compensation guarantee fund [5]. Companies do not have to pay additional costs which can reduce the burden on enterprises that have more money to innovative products.

\subsection{Learn from Hong Kong and Taiwan Put the Quality Guarantee Deposit into the Tourism Association Management Category}

Government can make the collection and management the quality guarantee deposit to the travel agency association management. It can improve the efficiency in the use of quality guarantee which can improve the efficiency in the use of quality guarantee. Learn from Hong Kong or Taiwan the management approach of the quality guarantee deposit. It is a part of the quality deposit paid by members of the association as the promotion funds.

\subsection{Strengthen the Management of Travel Agency}

All travel agents in Hong Kong must join the Travel Industry Council of Hong Kong. Taiwan has more than 90\% 
of the travel agencies to join the Taiwan travel quality assurance association. Tourism Association can effectively monitor the travel agencies. It can make standard to management the travel agency industry. It can promote reasonable and fair market competition and safeguard the interests of the entire travel agency industry. This can ensure the service quality of travel agencies and improve service levels and destination tourism image. This can attract more tourists come. There are more than 20,000 travel agencies in Mainland China. There are only 1145 travel agencies participate in travel agents association. The travel agency less constrained and the vicious competition harmed the interests of the tourism industry. Tourism Industry Association needs to strengthen the management of travel agencies and promote travel industry better development.

\section{Conclusion}

According to the "Tourism Law", the tourism industry association makes the industry management norms and service standards. The tourism industry association should manage the service quality of the members and organization's occupation moral education and professional training. It can improve the quality of employees. This indicates that mainland China has to further reform the management system of tourism industry. It can promote better development of tourism industry and tourism industry association. It is very important to actively promote the construction of management system of China's travel agency industry which should match tourism industry association's management system. The government administration should change its management functions, management systems and management. It can promote the construction of tourism industry association and strengthen the organization management functions. The government should further establish and improve the travel industry policies and regulations system, and create a good legal environment for the healthy development of travel agency industry association. The travel agency industry association should expand funding sources and methods to provide financial support for the normal operation and professional management of the travel agency industry association.

\section{References}

[1] http://www.cnta.gov.cn/ (In Chinese)

[2] http://www.tourism.gov.hk/(In Chinese)

[3] http://www.discoverhongkong.com/tc/index.jsp (In Chinese)

[4] http://www.tichk.org/public/website/b5/index.html (In Chinese)

[5] Yuan, L. and Zeng, Y.H. (2012) Reflection on Reform and Development of the Local Travel Agency Association. Journal of Hunan Administration Institute, 2, 41-44. (In Chinese)

[6] http://taiwan.net.tw/w1.aspx (In Chinese)

[7] Du, J. and Dai, B. (2000) Comparative Study on the Environment of Travel Agency System between China and Foreign Countries. Tourism Tribune, 1, 22-28. (In Chinese)

[8] Huang, L. and Wang, D. (2010) A Comparative Study of Travel Agencies between Mainland China and Foreign Countries. Technology Square, 9, 234-236. (In Chinese)

[9] Ma, C. (2002) The Government Leading Strategy and the Establishment of an Effective Management System of Tourism Industry. Journal of Xinyang Agricultural College, 12, 46-48. (In Chinese)

[10] Zhang, L.L. (2003) History Reform of Tourism Management System in China. Social Scientist, 2, 82-90. (In Chinese)

[11] Jiang, S. (2007) International Comparison and Illumination of Tourism Administrative System. Journal of Ezhou University, 14, 56-59. (In Chinese)

[12] Zhang, L.L. and Yuan, G.H. (2002) On the Role of Industry Associations in the Development of Tourism Management System in China. Social Scientist, 17, 30-34. (In Chinese)

[13] Rong, R., Qu, L.Y. and Ma, Y.F. (2013) Discussion of Reform Innovation of Tourism Management System in China from the Perspective of Tourism Trends. Journal of Green Science and Technology, 8, 299-302. (In Chinese)

[14] Lin, L.F. and Yuan, B. (2007) On Strengthening the Construction of China's Tourism Industry Association of Five Strategies. Ecological Economy, 2, 282-285. (In Chinese)

[15] Zhu, B. (2004) A Comparative Study of Travel Agencies between Chinese and Foreign Countries. Enterprise Economic, 2, 139-140. (In Chinese)

[16] Que, L.P. and Cheng, X.Z. (2002) Government and Industry Association with China Tourism Industry Management. Business Research, 6, 147-149. (In Chinese) 
Scientific Research Publishing (SCIRP) is one of the largest Open Access journal publishers. It is currently publishing more than 200 open access, online, peer-reviewed journals covering a wide range of academic disciplines. SCIRP serves the worldwide academic communities and contributes to the progress and application of science with its publication.

Other selected journals from SCIRP are listed as below. Submit your manuscript to us via either submit@scirp.org or Online Submission Portal.
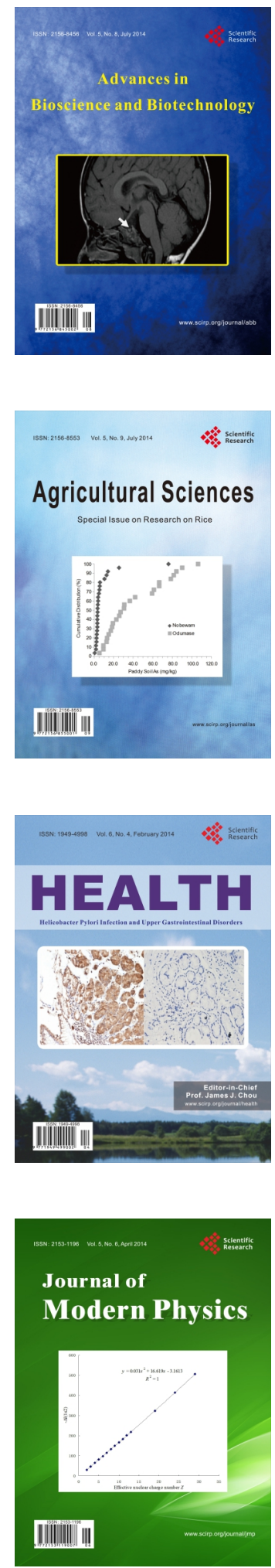
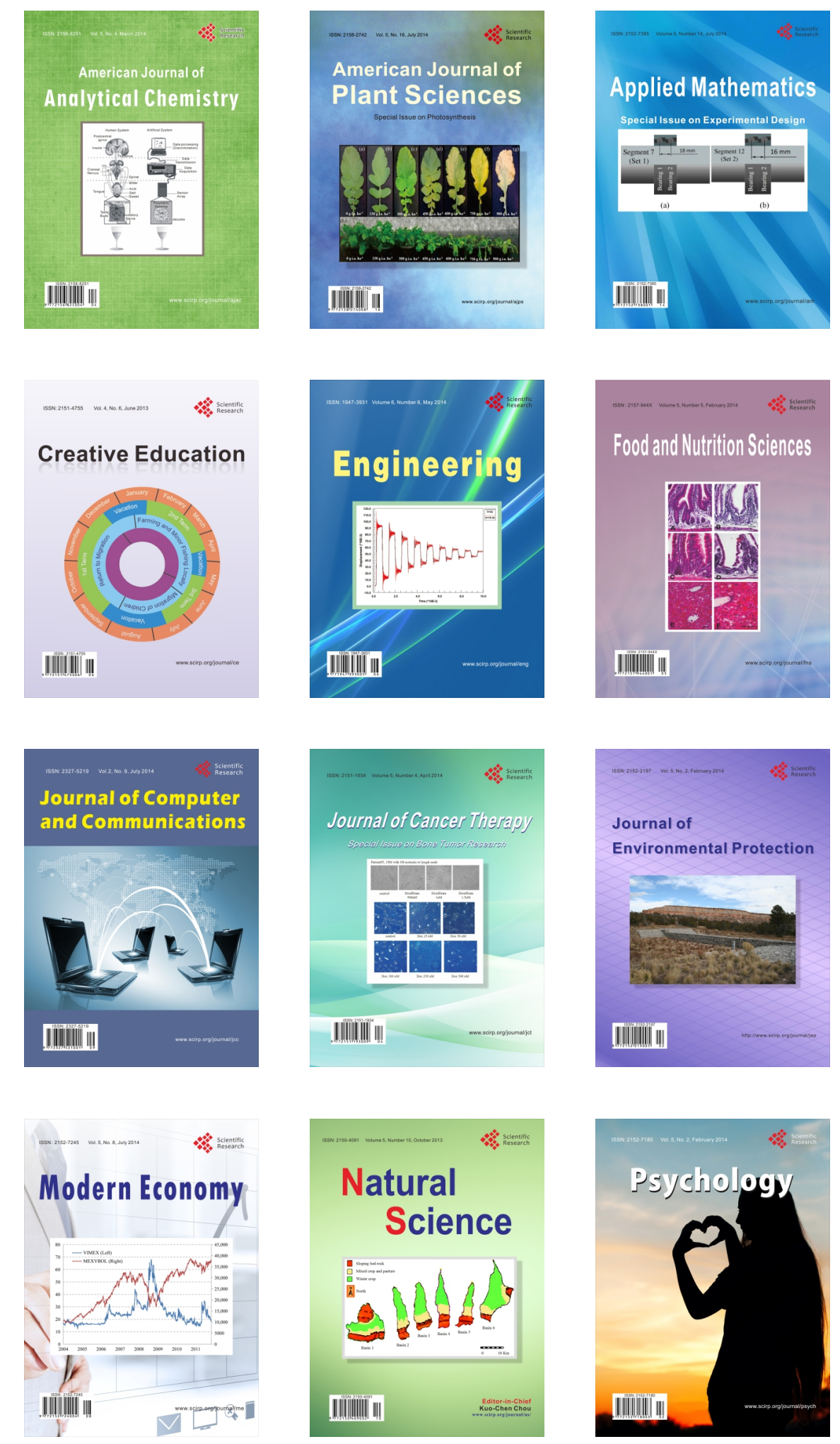